Journal of International Business and Economy (2021) 22 (1): 83-108 (26 pages)

\title{
COVID-19 IMPACT ON NIFTY BANKS: AN EVENT STUDY METHODOLOGY
}

\begin{abstract}
The financial sector, because of its catalytic role in the economy, has always been in the eye of the storm in economic difficulties. Due to the pandemic, the stock market had lost about 27 percent by April 2020 and bank nifty has had a lion's share in pushing the index down to this level. Uncertainty arose as the containment of the disease and the availability of vaccines remain uncertain; this contributed to the plunge in investor confidence. Because of the central role of banks in the development initiatives of the governments, COVID-19 has become a significant threat to the sustainability of the banks globally, especially in developing economies. However, we believe every downfall brings in new opportunities for the investors. Therefore, the present study attempted to study both the gloom and boon and observed that there were short-term abnormal returns to the investors of nifty banks in two different periods - the detection of the first case of COVID-19 in India and the lockdown periods in India. The impacts of both the events are calculated by applying Market and Risk Adjusted model, Market Adjusted Return model and Mean Adjusted Return model. The paper concludes that the impacts were insignificant during the first period and was quite significant in the subsequent period. Nifty banks have earned negative abnormal returns during the pre-lockdown period and positive abnormal returns during post lockdown period which indicates that the markets reacted positively as India implemented the first lockdown.

Key Words: COVID-19, Indian banks, Nifty, Share price reaction, Event study
\end{abstract}

Sabat Kumar Digal

Rama Devi Women's University

Yashmin Khatun

NIT Rourkela

Braja Sundar Seet

Independent Researcher 


\section{INTRODUCTION}

On 31st December, the world bumped into the most devastating epidemic COVID-19. The disease, which was originated from the Wuhan city of China, has spread all over the globe sparing none. Though the epidemic is not new to human beings as history is replete with their encounters with the epidemics with high mortality rate like Cholera, Ebola, SARS, etc., yet what makes COVID-19 (SARS-CoV-2) lethal is its ability to be easily transmitted from humans to humans, even among the asymptomatic patients (World Health Organization). Though the vaccine has been rolled out and jabs being given to the people, vaccine has not yet completed its final trial and many consider it is in its trial phase only. Many countries have reservations to the doses and with the emergence of the second streak in the UK and South Africa, many believe that it cannot be market-ready before the winter of 2021. Therefore, it is not judicious to pin our hopes on vaccines now, but follow the social distancing stringently to keep the disease at bay. However, on the other hand, the practice of social distancing and lockdowns so far have been disastrous on the finances. As per the IMF report, the global economy is going to shrink by over 3\% in 2020, the steepest fall after the 1929 Great Depression that led to unemployment, poverty, and starvation. As per the Centre for Monitoring Indian Economy (CMIE), during the early phase of the lockdown in 2020, India's unemployment rose up to 23\% from $8.75 \%$ as of March 2020.

World economies share the three main common goals: growth, high employment, and price stability. And these economic goals can be achieved when any country is financially healthy and sound (Mahajan, 2020). After the World Health Organization declared COVID19 as a pandemic, investors started withdrawing capital from the stock market, which resulted in the crash of the world stock market. The crash affected most industries with the worst hit on aviation, hotel, and tourism sectors. During the slowdown, the Banking and Financial Services and Insurance (BFSI) sector not only played a vital role in safeguarding the global economy but, in the process, it bore the maximum brunt and was one of the worst hits. To make the situation even worse, the COVID-19 outbreak came at a time when India's economy was already slowing, due to the persistent weakness of the financial sector (Mahajan, 2020). Due to COVID-19, nifty index declined by 27.7 percent and bank nifty index dipped by 40.1 percent throughout March, April, and May 2020. However, despite any extents of economic costs, human lives are precious. Saving human lives have always been the priority over saving the economy. There is no dilemma because lives and money cannot be equated. And therefore, global lockdowns were enforced to save human lives. But 
the lockdowns brought in challenges like demand-supply disequilibrium of consumer goods, survival problems for Micro, Small, and Medium Enterprises (MSMEs), livelihood problems for the poor people, etc. To solve the economic problems, the government and regulators have brought in different fiscal and monetary policies to help people and businesses to survive the pandemic.

"Financial institutions are at great risk due to COVID-19 as there could be lower business for lending institutions with private investments and consumption continued to decline both during the pandemic or even after it is over" (Barua, 2020). In line with the central banks of different countries, the Reserve Bank of India (RBI) has also taken various measures to revive the Indian economy from the slowdown by decreasing the bank rate, injections of liquidity, moratorium benefits in lockdown for the lenders, etc. Decreasing in bank rate helps the banks to provide loan to the customers at a lower rate which will help the business to cover their operating expenses and survive in the lockdown periods. Due to the less economic activities, there was a shortage of liquidity in the economy as a result of that RBI injected liquidity to safeguard the economy. RBI has also introduced a moratorium for credit for which the holders did not have to pay Equated Monthly Instalment (EMI) for a certain period. Such benefits helped people facing financial problems during the lockdown. These services were provided by the banks, and the banks, in turn, also expected some relaxations in areas like assets classification to ease the burden of increasing NonPerforming Assets (NPA), which directly affects the banks' performance and quarterly results.

In a developing country like India, the role of banking institutions in mobilizing the resources and converting the deposits into productive investments to maintain a sound and sustainable economy cannot be undermined. Nowadays, banking institutions face many problems. And staying profitable to provide better banking services to customers is one of the major problems that Indian banks are beset with today. The unexpected outbreak of COVID-19 marks an opportunity to evaluate the impacts of COVID-19 on Indian Banks and their preparedness for such future exigencies. Unusual events always affect the share price and investor sentiment. Later, investors faced with fear and anxiety start withdrawing their money from the market which leads to changes in portfolio return. Therefore, in this article, we have analyzed the impact of the outbreak of COVID-19 on the security prices of Indian banks traded in the National Stock Exchange (NSE) by applying event study methodology. 
The rest of the article is divided into four sections. The related theoretical and empirical literature on COVID-19 and its impact on the economy and performance of banks during financial crises are analyzed in section 2. Detailed discussion about the data and methodology are discussed in section 3 followed by the empirical evidence provided in Section 4. In the end, the paper summarizes the major findings of this research in section 5.

\section{REVIEW OF LITERATURE}

While considerable data analyzing the impact of COVID-19 on the Indian economy is available, there is limited research that analyzes the impact of COVID-19 on the banking industry. And it is even less and often found to be new area of analysis with regard to event study methodologies. The lack of studies in this line is indeed an opportunity to explore the unknown. Therefore, the current study is undertaken to throw more light and contribute to the existing scant literature in the field. The available literature reviews in the area are categorized into two sub-sections.

\section{COVID-19 outbreak and the economy}

The economy has widely been affected due to the COVID-19 outbreak. As the disease spread, the markets responded by weighing the economic consequences (Ramelli and Wagner, 2020). To measure the impact of COVID-19 on the overall economy, many actions viz., tax deferrals, cash transfers, extended unemployment benefits and social assistance and fiscal policy are required to be taken to maintain employment and wages (Mahajan, 2020). In a similar line, many have (Ozili, 2020) also recommended the use of fiscal policy to support individuals and businesses to revive the economy and financial assistance like this is a lifeline to vulnerable households and firms. Like in every pandemic, younger and lesseducated workers or new entrants will, unfortunately, suffer to the greatest extent. Therefore, the government policies should focus more on redressing the liquidity problems of SMEs, support vulnerable ones under financial distress, and help those secure jobs (Fernandes, 2020). Along similar lines, Singh (2020) added that the impact of COVID-19 on poverty and unemployment can be dealt with by providing credit facilities to migrant laborers and marginal farmers and wage subsidies to the informal sectors. He also recommended agricultural reforms, maintenance of law and order and keeping corruption under check for the successful implementation of policies. Though other researchers have focused more on 
the negative impacts of the pandemic, researchers like Jamir (2020) have found a positive impact of COVID-19. He pointed that the COVID-19 could promote the digital transformation of the economy and bring in increased transparency which can push FDI flows resulting in economic growth. Since, information about both the transacting parties is available online, digital transactions are more transparent and can contribute to the growth of the economy. As when the pandemic would end remains uncertain, what is important now is to plan and implement aggressive as well as ground-breaking policy to avoid its worst impacts (Barua, 2020). Business is one of the important elements which can help in the growth of the economy (Rakshit and Paul, 2020). Therefore, the focus should be on the impacts of COVID-19 on the business and important measures (Political, Economic, Social, Technological, Ecological and Legal) should be undertaken for the business organizations along with continuous internal analysis and steady move to digitization. Though the COVID-19 seems pervasive yet its impacts depend on social discipline, the effectiveness of the healthcare system, and progressive virtualization of economic and social life (Sułkowski, 2020).

The stock market is one of the many indicators to examine the growth and effectiveness of an economy. COVID-19 has impacted both the Indian and global stock markets (Alam, Alam, and Chavli, 2020) conducted a study to identify the responses of stock markets during the lockdown periods by applying event study methodology and found that the stock markets reacted negatively in the pre-lockdown period and positively in the post-lockdown period. Ashraf (2020) found that stock markets across the world reacted negatively to news of growth in a number of cases than growth in a number of deaths, as compared to Heyden and Heyden (2020), who in their study found that announcement of the first case had no impact on stock prices but the announcement of first death had a significant impact on share prices. Naidenova, Parshakov and Shakina (2020) conducted the study in similar lines and found that initial news of confirmed death had an insignificant impact but later social distancing led to a negative impact on financial markets. Liu, Manzoor, Wang, Zhang, and Manzoor (2020) added that stock markets of Asian countries reacted more swiftly to the epidemic and confirmed cases of COVID-19 only contributed towards the investor's fear which could be the reason behind such negative impacts. Therefore, it can be said that if the pandemic is not countered with effective jabs, the global financial system would possibly face the gravest threat seen in the last two centuries (Fernandes, 2020). 


\section{Performance of banks in the crisis}

Given the over-dependence of developing countries on bank finance, bank performance and the growth of the economy are interrelated. Despite their systemic importance, banks are not immune to external developments such as macro-economic variables like inflation, employment, GDP, etc. or man-made disasters and their performance, to a great extent, is dependent on the developments beyond their control. It is for all to see that the COVID19 has a considerable impact on the economy and banks could not get away with it. In fact, banks are more exposed to pandemic and crisis because of increased demand for disbursal of more loans to survive and revive the economy, which in turn creates more NPA. Financial institutions are in danger due to COVID-19 and there could be a decrease in activities as private sector investment and funding consumption continues to decline (Barua, 2020). Therefore, banks should focus more on digital services and, with an increased amount of credit default and market risk, banks need to work on their hedging strategies. Kumar and Bhatia (2017) applied event study methodology to measure the impacts of demonetization on banks listed in Bombay Stock Exchange and found both public, as well as private banks, reacted negatively to the news but, post demonetization period, public banks recorded highest average return as opposed to the private banks which registered lower average returns. It was further observed that the banks could survive and required less support during the crisis if they had a non-aggressive business model, strong funding model and balance sheet liquidity (Arjani and Paulin, 2013). During difficult times, banks with sufficient capital dealt with the crisis better than those without or less of it (Berger and Bouwman 2013). Few studies also observed that corporate governance had a huge role to play in crisis situations as a company with good corporate governance could lessen the negative influence of the catastrophes on banks (Peni and Vahamaa, 2011).

\section{METHODOLOGY}

\section{Data}

A total of twenty most representative banks operating in India (i.e., ten respectively from the private and public sectors) (See Table 1), were selected to evaluate the impacts of the COVID-19 outbreak in the share prices of these banks. 
Table 1. List of sample banks

\begin{tabular}{llc}
\hline Public sector banks & Private sector banks & \\
\hline State Bank of India (SBI) & Industrial Credit and Investment \\
& Corporation of India Bank (ICICI Bank) \\
Bank of Baroda (BOB) & Housing Development Finance \\
Central Bank & Corporation (HDFC Bank) & \\
Bank of India (BOI) & Axis Bank & \\
Canara Bank & Bandhan Bank & \\
Indian Bank & Federal Bank & \\
Indian Overseas Bank (IOB) & Infrastructure Development Finance \\
Punjab National Bank (PNB) & Company First Bank (IDFC First Bank) \\
United Commercial Bank (UCO Bank) & IndusInd Bank & \\
Union Bank & Kotak Mahindra Bank & \\
\hline
\end{tabular}

Keeping the objectives of the study, daily closing prices of these banks listed in the National Stock Exchange have been taken from the website of Yahoo Finance and nifty index share price has been used to calculate the market return.

\section{Event study set-up}

Event study methodology has been used to test the impacts of two major events related to COVID-19 on the share prices of nifty banks. The event study is an effective methodology in measuring the effects of a particular event on the behavior of security prices of a company. In addition to this, an event determines whether there is an 'abnormal' stock price effect associated with an unanticipated event (McWilliams and Siegel, 1997).

The disease caused by the novel coronavirus was first identified in Wuhan, China. The disease was declared as a pandemic by WHO on $31^{\text {st }}$ December 2019. On $30^{\text {th }} J a n u a r y$ 2020, the first case was identified in India, which represented the first event in our study. As before this event, the high-level expert group leader of the National Health and Fitness Commission of the People's Republic of China, Zhong Nanshan, opined in an interview that the new coronavirus could be transmitted among people, which led to wide public attention (Liu et al., 2020). So, the study attempts to assess if the news of $1^{\text {st }}$ confirmed case of the disease had any influence on the returns of the banks listed in NSE. Considering the faster contagion of the disease, each country has taken steps to contain the spread of the disease. Central government announced a complete lockdown for 21 days in India, in the first phase. This news broke the headlines on the night of $24^{\text {th }}$ March 2020 and the complete 
lockdown started from 25 th March 2020. The complete lockdown in a country halts the movements of people and vehicles, causing a great deal of economic distress. So, it is another event that can impact the share price. That is why it is taken as the second event for the purpose of the study. Therefore, it is attempted to assess each event and its impact on the share prices of nifty banks

The event window for both events has been selected as -10 through zero to +10 , where zero represents the event day and -10 , and +10 are the period before and after the event day. We have taken 90 days as the estimation window. It is because a long window may not give accurate results due to uncertainty in the stock market. In order to assess the significance of the events, t-test has also been applied.

\section{Test models}

Abnormal returns can be estimated by using statistical relationship models (i.e., Market and Risk Adjusted Return Model, Market Adjusted Return Model, or Mean Adjusted Return Model or on theoretical economic models like Capital Asset Pricing Model or Arbitrage Pricing Model). Statistical relationship models of event study have been used in this study in order to obtain abnormal returns. Using the abnormal returns variables, for abnormal returns, charts are generated showing the positive and negative impacts of the events. Abnormal returns result when an event is unanticipated. Security is able to earn an abnormal return when the performance of the security is different from what has been expected from the security.

\section{Market and risk adjusted return model}

This model is also known as OLS market model as this model considers market return as well as the market risk in calculation of abnormal returns of the security.

Abnormal Returns (AR) can be calculated as follow:

$A R_{i t}=R_{i t}-E_{i t}$

Where $\mathrm{AR}_{\mathrm{it}}$ is abnormal return for firm $\mathrm{i}$ for day $\mathrm{t}$,

$\mathrm{R}_{\mathrm{it}}$ is actual return for firm i for day $\mathrm{t}$,

And $E_{i t}$ is the expected return which can be calculated as: $\alpha+\beta *$ Rmt. $^{*} \varepsilon_{i t}$

$\alpha_{\mathrm{i}}=$ Intercept or alpha coefficient for security i

$\beta_{i}=$ Slope or beta coefficient for security $i$

$\mathrm{Rmt}=$ Actual returns of market (nifty) at time $\mathrm{t}$

$\varepsilon_{\mathrm{it}}=$ Error term of security $\mathrm{i}$ at time $\mathrm{t}$ 


\section{Market-adjusted return model}

This model does not consider market risk factor in calculation of AR of the security.

$\mathrm{AR}_{\mathrm{it}}=\mathrm{R}_{\mathrm{it}}-\mathrm{Rm}_{\mathrm{t}}$

$\mathrm{R}_{\mathrm{it}}$ and $\mathrm{Rm}_{\mathrm{t}}$ have been defined in market and risk adjusted return model.

\section{Mean-adjusted return model}

This model neither considers the risk factor nor the market return in the calculation of abnormal returns of the security.

$$
\mathrm{AR}_{\mathrm{it}}=\mathrm{R}_{\mathrm{it}}-\mathrm{Rx}_{\mathrm{t}}
$$

Where $\mathrm{Rx}_{\mathrm{it}}$ is the simple mean of security $\mathrm{i}$ at time $\mathrm{t}$.

In this study, the summation of the AR known as cumulative abnormal return is tested along with AR. In order to obtain the Cumulative Abnormal Return (CAR), following equation has been used:

$$
\mathrm{CAR}_{\mathrm{it}}=\sum \text { ARit }
$$

Each CAR is examined for its association with the unexpected events.

In this study, we have set -10 and +10 event windows for CAR. Where $(-)$ represents before the event day and $(+)$ represents after the event day.

$$
\operatorname{AAR} \tau=\frac{1}{N} \sum_{i=1}^{N} A R_{\mathrm{i}} \tau
$$

Where $A A R \tau$ is the average of $A R$ of all the firms

$\mathrm{N}$ is the total number of firms in the sample

$$
\operatorname{CAAR}_{\mathrm{t} 1 . \mathrm{t} 2}=\frac{1}{N} \sum_{t=t 1}^{t 2} A A R_{\mathrm{i}} \tau
$$

Where, CAAR is the Cumulative Average Abnormal Return, which is aggregation of AAR.

\section{Hypothesis}

Null hypothesis of the event study states that the event has no impact on the stock return. On the basis of that, and by studying different literatures like Alam et al. (2020), Liu et al. (2020) and Kumar and Bhatia (2017) eight hypotheses have been formulated stating that the two events of COVID-19 do not have any impact on the AR, CAR, AAR and CAAR of nifty banks. In order to achieve the aim of the study, the following null hypotheses are formulated: 
$H_{01}$ : There is no significant AR of nifty banks during the event window caused by detection of first case of COVID-19 in India.

$H_{02}$ : There is no significant $C A R$ of nifty banks during the event window caused by detection of first case of COVID-19 in India.

$H_{03}$ : There is no significant $A A R$ of nifty banks during the event window caused by detection of first case of COVID-19 in India.

$H_{04}$ : There is no significant $C A A R$ of nifty banks during the event window caused by detection of first case of COVID-19 in India.

$H_{05}$ : Implementation of lockdown has no effect on $A R$ of nifty banks.

$H_{06}$ : Implementation of lockdown bas no effect on $C A R$ of nifty banks.

$H_{07}$ : Implementation of lockdown bas no effect on nifty banks $A A R$.

$H_{08}$ : Implementation of lockedown has no effect on nifty banks $C A A R$.

We test the statistical significance of ARs and CARs using a simple t-test (Brown and Warner, 1985). AR, CAR, AAR, and CAAR; test statistics have been obtained by using MS Excel Descriptive analysis in order to test the null hypothesis. Acceptance of the null hypothesis will also reveal the insignificant impacts of the events on share prices. If the calculated t-value of AR, CAR and CAAR exceeds the critical t-value at a five or ten percent level of significance, the null hypothesis is rejected. Rejection of the null hypothesis will suggest that the events have a significant impact on the security prices of the nifty banks and it indicates the investors have the opportunity to get an abnormal return from the security.

\section{FINDINGS}

The empirical study is summarized in the following tables and graphs. The findings of the study have been divided into two parts. Part I discusses the impacts of event number 1, which is the detection of the first case of covid-19 in India, on the share prices of selected nifty banks. In Part II, the impacts of the measures taken, in the form of the $1^{\text {st }}$ lockdown, on share prices of nifty banks in India are discussed.

\section{Detection of first case of COVID-19 in India}


Table 2 reports the AR on the event day and one day after the event day by nifty banks. AR of all banks have been obtained by using the market and risk adjusted return model, market adjusted return model and mean adjusted return model. It is evident from the tables that on the event day only Infrastructure Development Finance Company First bank (IDFC First bank) had significant negative AR which means that only IDFC First bank's prices reacted to the news on the event day and no other banks reacted to the event resulting in insignificant effect of the event on the share prices of the nifty banks on the event day. The significance of the event can also be seen from the t-statistics of AR, where t-statistics of all banks, except IDFC First bank, are less than the critical value at 10\% and 5\% level of significance in all three models. This indicates the acceptance of the null hypothesis (i.e., the event of detection of first case of COVID-19 in India has no significant impact on the share prices of the nifty banks). Bank of India (BOI) and State Bank of India (SBI) have reacted to the aforesaid event on one day after the event as both the banks have significant $\mathrm{AR}$ as its t-statistics is less than the critical value. Later Axis bank, Bandhan bank, Federal bank, IndusInd bank, and Kotak bank also reacted on the $4^{\text {th }}$ day after the event. It can be inferred that only a few bank's share prices reacted on event day and one day after the event. But overall, the event had no significant impact on the bank's share price as t-statistics is less than the critical value for all the event windows. Thus, the null hypothesis cannot be rejected which indicates the aforesaid event does not have any impact on the share prices of nifty banks.

Table 2. AR and T-statistics of AR

\begin{tabular}{|c|c|c|c|c|c|c|c|c|c|c|c|c|}
\hline \multirow{3}{*}{$\begin{array}{l}\text { Model } \\
\text { Banks }\end{array}$} & \multicolumn{4}{|c|}{$\begin{array}{l}\text { Market and risk adjusted return } \\
\text { model }\end{array}$} & \multicolumn{4}{|c|}{ Market adjusted return model } & \multicolumn{4}{|c|}{ Mean Adjusted Return Model } \\
\hline & \multicolumn{2}{|c|}{ on the event day } & \multicolumn{2}{|c|}{$\begin{array}{l}\text { one day after the } \\
\text { event }\end{array}$} & \multicolumn{2}{|c|}{ on the event day } & \multicolumn{2}{|c|}{$\begin{array}{l}\text { one day after the } \\
\text { event }\end{array}$} & \multicolumn{2}{|c|}{$\begin{array}{l}\text { On the Event } \\
\text { Day }\end{array}$} & \multicolumn{2}{|c|}{$\begin{array}{l}\text { One Day After } \\
\text { the Event }\end{array}$} \\
\hline & $\operatorname{AR}(\%)$ & $\begin{array}{c}\text { T- } \\
\text { statistics }\end{array}$ & $\operatorname{AR}(\%)$ & $\begin{array}{c}\text { T- } \\
\text { statistics }\end{array}$ & $\mathrm{AR}(\%)$ & $\begin{array}{c}\text { T- } \\
\text { statistics }\end{array}$ & $\mathrm{AR}(\%)$ & $\begin{array}{c}\text { T- } \\
\text { statistics }\end{array}$ & $\mathrm{AR}(\%)$ & $\begin{array}{c}\text { T- } \\
\text { statistics }\end{array}$ & $\mathrm{AR}(\%)$ & $\begin{array}{c}\text { T- } \\
\text { statistics } \\
\end{array}$ \\
\hline HDFC & 1.19 & 1.13 & 0.54 & 0.51 & 1.22 & 1.16 & 0.57 & 0.54 & 0.25 & 0.24 & -0.24 & -0.22 \\
\hline ICICI & 2.07 & 1.47 & -0.46 & -0.33 & 1.83 & 1.30 & -0.62 & -0.44 & 0.71 & 0.50 & -1.58 & -1.12 \\
\hline Axis & 0.72 & 0.62 & 0.84 & 0.72 & 0.18 & 0.16 & 0.40 & 0.34 & -0.75 & -0.65 & -0.38 & -0.33 \\
\hline $\begin{array}{l}\text { Bandh } \\
\text { an } \\
\text { Bank }\end{array}$ & -1.76 & -0.60 & 3.88 & 1.32 & -2.25 & -0.77 & 3.46 & 1.18 & -3.12 & -1.06 & 2.76 & 0.94 \\
\hline $\begin{array}{l}\text { Federal } \\
\text { Bank }\end{array}$ & -0.31 & -0.21 & -0.44 & -0.30 & -1.19 & -0.81 & -1.18 & -0.80 & -2.09 & -1.42 & -1.91 & -1.30 \\
\hline
\end{tabular}




\begin{tabular}{|c|c|c|c|c|c|c|c|c|c|c|c|c|}
\hline $\begin{array}{l}\text { IDFC } \\
\text { First }\end{array}$ & -6.77 & $-3.86^{* *}$ & 0.71 & 0.40 & -7.01 & -4.00 & 0.49 & 0.28 & -7.84 & -4.47 & -0.17 & -0.10 \\
\hline $\begin{array}{l}\text { Indusi } \\
\text { nd }\end{array}$ & -0.24 & -0.11 & 3.77 & $1.83^{*}$ & -1.37 & -0.67 & 2.81 & 1.36 & -2.19 & -1.06 & 2.15 & 1.04 \\
\hline Kotak & 0.01 & 0.01 & 4.42 & 4.04 & 0.03 & 0.03 & 4.44 & 4.05 & -0.93 & -0.85 & 3.64 & 3.32 \\
\hline Rbl & -1.47 & -0.42 & 0.76 & 0.22 & -3.18 & -0.92 & -0.65 & -0.19 & -4.07 & -1.17 & -0.89 & -0.61 \\
\hline $\begin{array}{l}\text { South } \\
\text { bank }\end{array}$ & -1.45 & -0.87 & -1.18 & -0.71 & -1.54 & -0.93 & -1.28 & -0.77 & -1.38 & -0.40 & -0.74 & -0.50 \\
\hline SBI & -0.13 & -0.07 & 3.85 & $1.99 * *$ & -1.04 & -0.54 & 3.11 & 1.64 & -2.03 & -1.05 & 2.29 & 1.18 \\
\hline BOB & 0.79 & 0.44 & 0.74 & 0.41 & 0.13 & 0.07 & 0.18 & 0.10 & -0.72 & -0.40 & -0.51 & -0.28 \\
\hline BoI & 1.10 & 0.64 & 3.87 & $2.25^{* *}$ & 0.25 & 0.14 & 3.15 & $1.83^{*}$ & -0.63 & -0.37 & 2.93 & $1.65^{*}$ \\
\hline $\begin{array}{l}\text { Canara } \\
\text { Bank }\end{array}$ & -0.02 & 0.41 & 2.22 & 0.87 & -0.14 & -0.08 & 0.81 & 0.47 & -1.02 & -0.59 & 0.08 & 0.05 \\
\hline $\begin{array}{l}\text { Central } \\
\text { Bank }\end{array}$ & -0.34 & -0.19 & -1.37 & -0.77 & 0.78 & 0.44 & -0.41 & -0.23 & -0.35 & -0.20 & -1.37 & -0.77 \\
\hline $\begin{array}{l}\text { Indian } \\
\text { Bank }\end{array}$ & 0.52 & 0.17 & 1.80 & 0.59 & -0.10 & -0.03 & 1.15 & 0.38 & -0.23 & -0.08 & 1.17 & 0.39 \\
\hline IOB & -1.51 & -0.52 & -0.17 & -0.06 & -1.16 & -0.394 & 0.13 & 0.043 & -2.07 & -0.70 & -0.62 & -0.21 \\
\hline PNB & -0.18 & -0.10 & 2.03 & 1.17 & -0.88 & -0.50 & 1.44 & 0.83 & -1.73 & -0.99 & 0.76 & 0.43 \\
\hline UCO & -1.14 & 0.79 & 0.62 & 0.88 & -1.14 & -0.27 & 0.61 & 0.15 & -1.99 & -0.47 & -0.07 & -0.02 \\
\hline $\begin{array}{l}\text { Union } \\
\text { Bank }\end{array}$ & 0.09 & 0.04 & 0.14 & 0.06 & -0.99 & -0.41 & -0.78 & -0.32 & -1.74 & -0.73 & -1.37 & -0.57 \\
\hline
\end{tabular}

* indicates significant at $10 \%$ level of significance. ** indicates significant at 5\% level of significance.

Source: Author's own estimation

In table 3, CAR and t-statistics of CAR for 10 days before and 10 days after the event day of all three models are given. All the banks had insignificant CAR before the event as 10 CAR of all the banks seems to be insignificant in all three models with t-statistics is less than the critical value at $5 \%$ and $10 \%$ level of significance. Canara bank had significant +10 CAR in all the models. Whereas, Indian bank, Indian Overseas Bank (IOB), Punjab National Bank (PNB) and South bank had significant +10 CAR in two models i.e., market and risk 
adjusted return model and market adjusted return model. Overall, t-values appear to be inconsistently significant before and after event days.

The results of the daily AAR, which are the average of abnormal return of all 20 banks are shown in table 4. By calculating the average returns of all the banks, impacts of the event on the bank performance can precisely be known. The result indicates that all the AARs are insignificant in the event window as t-statistics is less than critical value. The result can also be inferred through the $\mathrm{p}$-value of AAR. It can be evidenced that $\mathrm{p}$ values of AAR in all the event windows are more than 0.05 at $5 \%$ level of significance and 0.1 at $10 \%$ level of significance. This shows that the banks did not reap any abnormal return during the event period. This means that the null hypothesis is accepted i.e., the event has no impact on the share prices of nifty banks.

Table 3. CAR and T statistics of CAR of $1^{\text {st }}$ Event

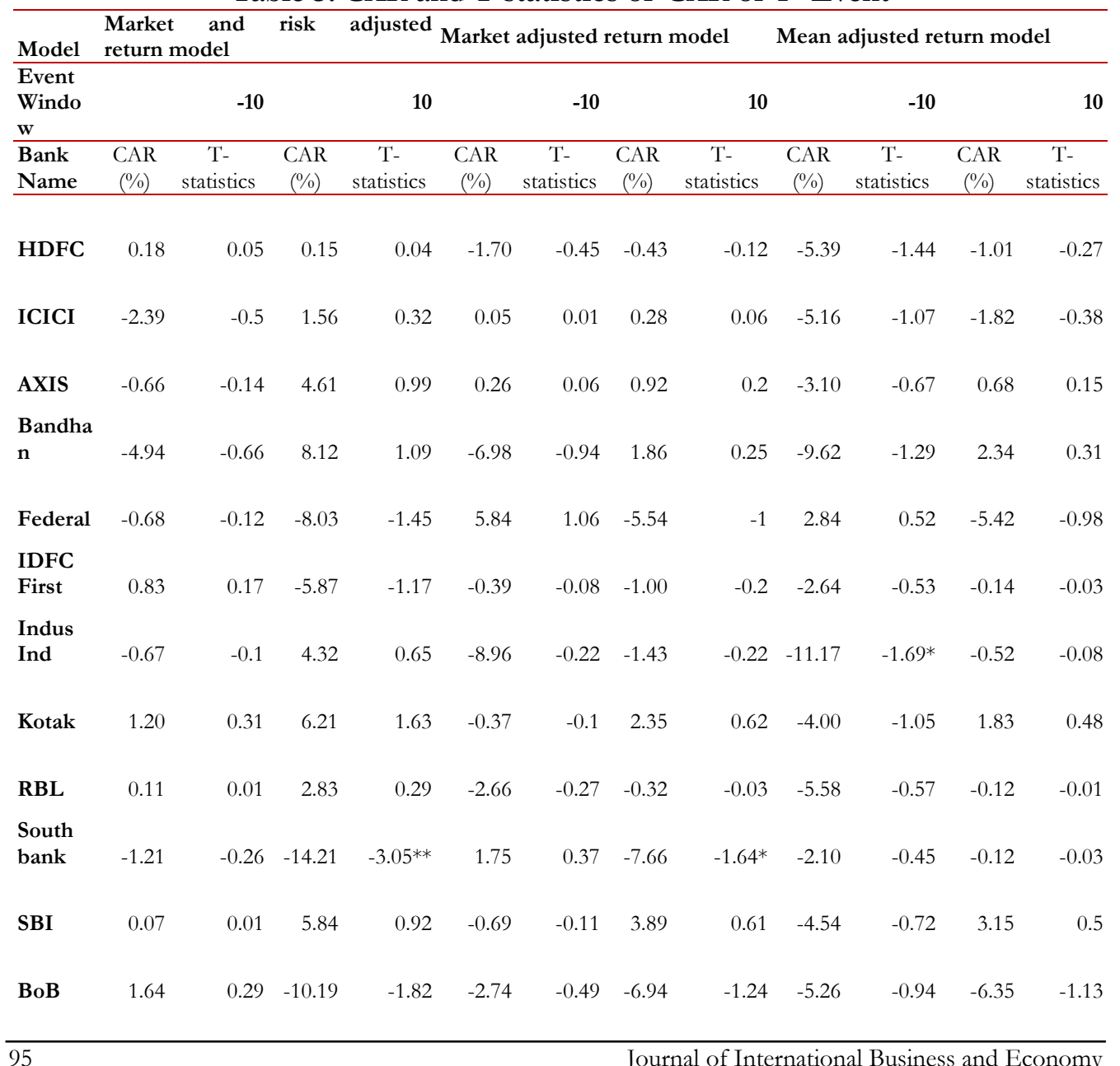




\begin{tabular}{|c|c|c|c|c|c|c|c|c|c|c|c|c|}
\hline $\begin{array}{l}\text { Cental } \\
\text { Bank }\end{array}$ & -1.10 & -0.25 & -0.41 & -0.09 & 0.06 & 0.01 & 1.05 & 0.24 & -5.16 & -1.16 & -1.07 & -0.24 \\
\hline BoI & -0.57 & -0.1 & -8.03 & -1.39 & -2.24 & -0.39 & -6.01 & -1.04 & -5.04 & -0.87 & -5.71 & -0.98 \\
\hline $\begin{array}{l}\text { Canara } \\
\text { Bank }\end{array}$ & -2.85 & -0.49 & -18.91 & $-3.26^{* *}$ & -4.91 & -0.85 & -11.37 & $-1.96 * *$ & -7.79 & -1.34 & -11.13 & $-1.92^{*}$ \\
\hline $\begin{array}{l}\text { Indian } \\
\text { Bank }\end{array}$ & -0.97 & -0.13 & -15.84 & $-2.16^{* *}$ & 6.38 & 0.87 & -16.84 & $-2.30^{* *}$ & 11.05 & 1.51 & -9.06 & -1.23 \\
\hline IOB & -3.44 & -0.5 & -18.74 & $-2.7^{* *}$ & -7.39 & -1.07 & -8.44 & -1.22 & -10.48 & -1.51 & -8.41 & -1.21 \\
\hline PNB & -0.45 & -0.08 & -15.72 & $-2.83^{* *}$ & -2.19 & -0.39 & -9.26 & $-1.67 *$ & -4.67 & -0.84 & -8.62 & -1.55 \\
\hline UCO & -0.5 & -0.06 & -12.68 & -1.3 & -0.44 & -0.04 & -7.67 & -0.78 & -2.93 & -0.3 & -7.05 & -0.72 \\
\hline Union & -0.22 & -0.03 & -5.80 & -0.83 & -0.46 & -0.07 & -5.71 & -0.82 & -2.01 & -0.29 & -4.14 & -0.59 \\
\hline
\end{tabular}

Table 4 AAR and T-statistics of AAR

\begin{tabular}{|c|c|c|c|c|c|c|c|c|c|}
\hline \multirow[b]{2}{*}{$\begin{array}{l}\text { Event } \\
\text { Days }\end{array}$} & \multirow{2}{*}{$\begin{array}{l}\text { Market } \\
\text { return mode } \\
\text { AAR }(\%)\end{array}$} & \multirow{2}{*}{$\begin{array}{l}\text { and risk } \\
\text { el } \\
\text { T-Statistics }\end{array}$} & \multirow{2}{*}{$\begin{array}{l}\text { adjusted } \\
\text { P-Value }\end{array}$} & \multicolumn{3}{|c|}{ Market adjusted return model } & \multicolumn{3}{|c|}{ Mean adjusted return model } \\
\hline & & & & $\operatorname{AAR}(\%)$ & T-Statistics & P-Value & $\operatorname{AAR}(\%)$ & T-Statistics & P-Value \\
\hline-10 & -0.05 & -0.04 & 0.97 & -0.13 & -0.10 & 0.92 & -0.12 & -0.07 & 0.95 \\
\hline-9 & -0.54 & -0.43 & 0.67 & -0.69 & -0.52 & 0.61 & -0.80 & -0.43 & 0.67 \\
\hline-8 & 1.13 & 0.91 & 0.38 & 0.47 & 0.36 & 0.72 & -0.65 & -0.35 & 0.73 \\
\hline-7 & 0.79 & 0.64 & 0.53 & 0.43 & 0.33 & 0.75 & -0.10 & -0.06 & 0.96 \\
\hline-6 & -0.33 & -0.26 & 0.79 & -0.72 & -0.55 & 0.59 & -1.33 & -0.72 & 0.48 \\
\hline-5 & 0.34 & 0.27 & 0.79 & 0.50 & 0.38 & 0.71 & 1.02 & 0.55 & 0.59 \\
\hline-4 & -0.29 & -0.23 & 0.82 & -0.15 & -0.11 & 0.91 & 0.32 & 0.17 & 0.86 \\
\hline-3 & -1.48 & -1.19 & 0.25 & -0.55 & -0.42 & 0.68 & -1.70 & -0.92 & 0.37 \\
\hline-2 & 1.32 & 1.06 & 0.30 & 0.93 & 0.70 & 0.49 & 0.32 & 0.17 & 0.87 \\
\hline-1 & -1.34 & -1.08 & 0.29 & -1.18 & -0.88 & 0.39 & -0.65 & -0.35 & 0.73 \\
\hline 0 & 0.64 & 0.51 & 0.61 & 0.12 & 0.09 & 0.93 & -0.75 & -0.40 & 0.69 \\
\hline 1 & 0.34 & 0.27 & 0.79 & -0.10 & -0.08 & 0.94 & -0.80 & -0.43 & 0.67 \\
\hline 2 & -1.47 & -1.18 & 0.25 & -2.88 & $-2.17 * *$ & 0.04 & -5.51 & $-2.97 * *$ & 0.01 \\
\hline 3 & -0.28 & -0.22 & 0.83 & -0.22 & -0.16 & 0.87 & 0.09 & 0.05 & 0.96 \\
\hline 4 & -0.91 & -0.73 & 0.47 & 0.10 & 0.07 & 0.94 & 2.30 & 1.24 & 0.23 \\
\hline 5 & 0.25 & 0.20 & 0.84 & 0.57 & 0.43 & 0.67 & 1.39 & 0.75 & 0.46 \\
\hline 6 & 0.41 & 0.33 & 0.75 & 0.47 & 0.36 & 0.73 & 0.79 & 0.43 & 0.68 \\
\hline 7 & 1.99 & 1.60 & 0.13 & 1.69 & 1.27 & 0.22 & 1.28 & 0.69 & 0.50 \\
\hline 8 & -0.05 & -0.04 & 0.97 & -0.46 & -0.34 & 0.73 & -1.10 & -0.59 & 0.56 \\
\hline 9 & -1.35 & -1.08 & 0.29 & -1.17 & -0.88 & 0.39 & -0.62 & -0.33 & 0.74 \\
\hline
\end{tabular}




\begin{tabular}{cccccccccc}
10 & -1.32 & -1.06 & 0.30 & -1.08 & -0.81 & 0.43 & -0.40 & -0.21 & 0.83 \\
\hline * indicates significant at $10 \%$ level of significance.
\end{tabular}

$* *$ indicates significant at $5 \%$ level of significance.

CAAR is the summation of AAR. The t-statistics and p-value of CAAR is presented in table 5. It is clear from the table 5 that the event has not impacted the share prices of nifty banks as t-statistics is less than the critical value and $p$ value is more than 0.05 and 0.1 at $5 \%$ and $10 \%$ level of significance, respectively. It is also seen that there is no significant influence of the detection of first case of COVID-19 on share prices of both public and private banks. The reasons behind the insignificant impact could be due to the followings:

- Lack of proof regarding the human-to-human transmission of the infectious disease in the early stages.

- Delay in guidelines issued by the WHO regarding the hazardous impact of COVID-19.

Table 5. T-statistics of CAAR of event 1

\begin{tabular}{rrrrrrr}
\hline \multirow{2}{*}{ Model } & \multicolumn{2}{l}{$\begin{array}{l}\text { Market and risk } \\
\text { adjusted return model }\end{array}$} & \multicolumn{2}{l}{$\begin{array}{l}\text { Market adjusted } \\
\text { return model }\end{array}$} & \multicolumn{3}{l}{$\begin{array}{l}\text { Mean adjusted } \\
\text { return model }\end{array}$} \\
\hline Event Days & \multicolumn{1}{l}{ T-Statistics } & P-Value & \multicolumn{1}{l}{ T-Statistics } & P-Value & T-Statistics & P-Value \\
\hline $\mathbf{- 1 0}$ & -0.11 & 0.91 & -0.23 & 0.82 & -0.63 & 0.54 \\
10 & -0.61 & 0.55 & -1.18 & 0.25 & -0.44 & 0.67 \\
\hline
\end{tabular}

* indicates significant at $10 \%$ level of significance.

** indicates significant at $5 \%$ level of significance.

Source: Author's own estimation

\section{Effects of the $\mathbf{1}^{\text {st }}$ lockdown on share prices of nifty banks}

On 25th March, 2020, as a preventive measure against COVID-19, Prime Minister announced 21 days lockdown bringing the movements of 1.3 billion populations to a grinding halt. The market reacted positively to the aforesaid event as the AR of not only public banks but also private banks increased. Before the event, most of the banks had negative abnormal returns. Table 6 portrays the AR and t-statistics of all banks, which shows that the aforesaid event has influenced the share prices of most of the banks. On the event day, share prices of Industrial Credit and Investment Corporation of India (ICICI), Axis, IDFC First, Kotak, Canara, Central bank PNB, SBI, Bank of Baroda (BOB), and Indian Bank reacted positively to the news whereas Housing Development Finance Corporation 
(HDFC) bank, Bandhan, Federal and IndusInd bank reacted to the news negatively one day after the event. It can be seen that there are significant negative ARs during the prelockdown period and positive ARs during the post-lockdown period. The t-statistics of AR of all the banks in a sample is higher than the critical value indicating the rejection of the null hypothesis which means that the event has a significant impact on the share prices of nifty banks.

Table 7 represents the CAR and t-statistics of CAR of the $2^{\text {nd }}$ event. The t-statistics of before and after the event are highly significant. CAR is also seen to be significantly negative in the pre-event window. On 11 th March, 2020, WHO declared the COVID-19 as a pandemic creating havoc among the investors all over the world. Thus, the fear of COVID-19 made investors anxious and they started pulling out their money from the stock markets, which could be the reason for such negative ARs and CARs. While the after-event scenario is completely different from pre-lockdown period as the banks have positive CARs and t-statistics are significant as well. It infers that lockdown announcements did enhance the share prices of banks in the sample.

The results of the daily AAR are shown in table 8 . The results indicate that most of the AARs are significant in the event windows as t-statistics is more than a critical value. The results can also be inferred through the p-value of AAR, which is less than 0.05 at $5 \%$ and 0.1 at $10 \%$ level of significance in all the event windows. This means the banks had earned abnormal returns during the event period rejecting the null hypothesis i.e., the event has no impact on the share prices of nifty banks.

The t-statistics and p-value of CAAR are presented in table 9. It is clear from the table that the event has impacted the share prices of nifty banks as t-statistics is more than the critical value and p-value is less than 0.05 and 0.1 at $5 \%$ and $10 \%$ level of significance, respectively. There is a significant influence of the implementation of lockdown on the share prices of nifty banks. It can be inferred that the lockdown was viewed positively by the investors as an effective tool to contain the spread of the virus, because the sector earned positive abnormal returns. 
Table 6. AR and T-statistics of AR of $2^{\text {nd }}$ Event

\begin{tabular}{|c|c|c|c|c|c|c|c|c|c|c|c|c|}
\hline \multirow{3}{*}{$\begin{array}{l}\text { Model } \\
\text { Banks }\end{array}$} & \multicolumn{4}{|c|}{$\begin{array}{l}\text { Market and risk adjusted return } \\
\text { model }\end{array}$} & \multicolumn{4}{|c|}{ Market adjusted return model } & \multicolumn{4}{|c|}{ Mean adjusted return Model } \\
\hline & \multirow{2}{*}{$\begin{array}{l}\begin{array}{l}\text { on the } \\
\text { day }\end{array} \\
\mathrm{AR} \\
(\%)\end{array}$} & \multirow{2}{*}{$\begin{array}{c}\text { e event } \\
\text { T- } \\
\text { statistics }\end{array}$} & \multirow{2}{*}{\multicolumn{2}{|c|}{$\begin{array}{l}\begin{array}{l}\text { one day after } \\
\text { the event }\end{array} \\
\begin{array}{l}\mathrm{AR} \\
(\%)\end{array} \\
\begin{array}{c}\mathrm{T}- \\
\text { - }\end{array} \\
\end{array}$}} & \multirow{2}{*}{$\begin{array}{l}\begin{array}{l}\text { on the } \\
\text { day }\end{array} \\
\mathrm{AR} \\
(\%)\end{array}$} & \multirow{2}{*}{$\begin{array}{c}\text { event } \\
\text { T- } \\
\text { statistics }\end{array}$} & \multirow{2}{*}{$\begin{array}{c}\begin{array}{l}\text { one da } \\
\text { the even }\end{array} \\
\text { AR } \\
(\%)\end{array}$} & \multirow{2}{*}{$\begin{array}{l}\text { ay after } \\
\text { nt } \\
\text { T- } \\
\text { statistics }\end{array}$} & \multirow{2}{*}{$\begin{array}{l}\begin{array}{l}\text { on the } \\
\text { day }\end{array} \\
\mathrm{AR} \\
(\%)\end{array}$} & \multirow{2}{*}{$\begin{array}{l}\text { event } \\
\text { T- } \\
\text { statistic } \\
\mathrm{s}\end{array}$} & \multicolumn{2}{|c|}{$\begin{array}{l}\text { One Day After } \\
\text { the Event }\end{array}$} \\
\hline & & & & & & & & & & & $\begin{array}{l}\text { AR } \\
(\%)\end{array}$ & $\begin{array}{c}\mathrm{T}- \\
\text { statistics }\end{array}$ \\
\hline HDFC & 0.07 & 0.04 & 8.75 & $5.58^{* *}$ & 12.87 & $8.21 * *$ & 6.48 & $4.13^{* *}$ & -1.03 & -0.66 & 8.95 & 5.71 ** \\
\hline ICICI & 4.87 & $3.08^{* *}$ & 4.49 & $2.84^{* *}$ & 20.56 & $12.98^{* *}$ & 1.65 & 1.04 & 6.69 & $4.22^{* *}$ & 4.16 & $2.63 * *$ \\
\hline Axis & 6.22 & $3.85^{* *}$ & 4.84 & $3.00^{* *}$ & 21.42 & $13.27 * *$ & 1.89 & 1.17 & 7.71 & $4.78^{* *}$ & 4.57 & $2.83^{* *}$ \\
\hline $\begin{array}{l}\text { BAND } \\
\text { HAN } \\
\text { Bank } \\
\text { FEDER }\end{array}$ & 1.80 & 0.74 & $\begin{array}{r}32.7 \\
6\end{array}$ & $13.47^{* *}$ & 9.91 & $4.07^{* *}$ & 30.69 & $12.62^{* *}$ & -3.44 & -1.41 & 33.71 & $13.8^{* *}$ \\
\hline $\begin{array}{l}\text { AL } \\
\text { BANK }\end{array}$ & -1.31 & -0.59 & 9.38 & $4.22 * *$ & 15.22 & $6.85^{* *}$ & 6.27 & $2.82^{* *}$ & 1.45 & 0.65 & 8.88 & $4.00^{* *}$ \\
\hline $\begin{array}{l}\text { IDFC } \\
\text { FIRST }\end{array}$ & 7.53 & $2.21 * *$ & -4.54 & $3.04 * *$ & 20.73 & $9.21 * *$ & 3.69 & $1.64^{*}$ & 7.11 & $3.16^{* *}$ & 6.44 & $2.86^{* *}$ \\
\hline $\begin{array}{l}\text { INDUS } \\
\text { IND }\end{array}$ & -5.73 & -1.22 & 37.3 & $14.45^{* *}$ & 10.30 & $3.99 * *$ & 34.45 & $13.34^{* *}$ & -3.20 & -1.24 & 37.33 & $14.5^{* *}$ \\
\hline KOTAK & 8.51 & $6.37 * *$ & 6.72 & $5.03^{* *}$ & 25.15 & $18.84^{* *}$ & 3.74 & $2.80 * *$ & 11.25 & $8.42^{* *}$ & 6.22 & $4.66^{* *}$ \\
\hline RBL & 0.44 & 0.11 & 3.41 & 0.83 & -0.15 & -0.04 & 3.29 & 1.51 & 4.41 & 1.07 & 2.69 & 0.65 \\
\hline $\begin{array}{l}\text { SOUTH } \\
\text { BANK }\end{array}$ & 4.42 & $2.03^{* *}$ & 5.59 & $2.57^{* *}$ & 17.95 & $4.37^{* *}$ & 14.90 & $6.84^{* *}$ & 1.37 & 0.63 & 6.14 & $2.82^{* *}$ \\
\hline SBI & 5.81 & $2.52^{* *}$ & 1.19 & 0.52 & 17.44 & $7.55^{* *}$ & -0.96 & $-0.74 * *$ & 3.61 & 1.57 & 1.59 & 0.69 \\
\hline BOB & 3.10 & 1.32 & -3.19 & -1.35 & 18.83 & $7.99 * *$ & -6.42 & $-2.72 * *$ & 5.29 & $2.24^{* *}$ & -3.59 & -1.52 \\
\hline BoI & 2.64 & 1.15 & 4.57 & $2.00^{* *}$ & 13.90 & $6.07^{* *}$ & 1.84 & 0.80 & 0.63 & 0.27 & 4.94 & $2.16^{* *}$ \\
\hline $\begin{array}{l}\text { Canara } \\
\text { Bank }\end{array}$ & 5.51 & $2.11^{* *}$ & 4.76 & $1.82 *$ & 17.87 & $6.83^{* *}$ & 1.91 & 0.73 & 4.52 & $1.73^{*}$ & 4.94 & $1.89^{*}$ \\
\hline $\begin{array}{l}\text { Central } \\
\text { Bank }\end{array}$ & 15.4 & $9.52^{* *}$ & 9.99 & $6.16^{* *}$ & 25.03 & $15.44^{* *}$ & 8.21 & $5.07 * *$ & 11.19 & $6.91 * *$ & 10.76 & $6.64 * *$ \\
\hline $\begin{array}{l}\text { Indian } \\
\text { Bank }\end{array}$ & 6.31 & $2.81^{* *}$ & 3.84 & $1.71 *$ & 14.83 & $6.61 * *$ & 1.46 & 0.65 & 1.67 & 0.75 & 4.69 & $2.09 * *$ \\
\hline IOB & 4.26 & 1.45 & 3.97 & 1.35 & 15.34 & $5.21 * *$ & 1.72 & 0.58 & 1.68 & 0.57 & 4.44 & 1.51 \\
\hline PNB & 11.2 & $-2.79 * *$ & 6.02 & -0.72 & 8.24 & $3.30 * *$ & -5.14 & $-2.06^{* *}$ & -5.14 & $-2.06^{* *}$ & -2.13 & -0.85 \\
\hline UCO & 2.79 & 0.68 & 1.47 & $1.68^{*}$ & 9.33 & $2.26^{* *}$ & 0.97 & 0.24 & -4.43 & -1.07 & 3.59 & 0.87 \\
\hline Union & 2.27 & 0.55 & 1.70 & 1.38 & 11.88 & $3.84^{* *}$ & 2.43 & 0.78 & -1.45 & -0.47 & 5.49 & $1.77^{*}$ \\
\hline
\end{tabular}

$*$ indicates significant at $10 \%$ level of significance.

** indicates significant at $5 \%$ level of significance.

Source: Author's own estimation 
Table 7. CAR and T statistics of CAR of $2^{\text {nd }}$ Event

\begin{tabular}{|c|c|c|c|c|c|c|c|c|c|c|c|c|}
\hline \multirow{3}{*}{$\begin{array}{l}\text { Event } \\
\text { Window } \\
\text { s } \\
\text { Bank } \\
\text { Name }\end{array}$} & \multicolumn{4}{|c|}{$\begin{array}{l}\text { Market and risk adjusted return } \\
\text { model }\end{array}$} & \multicolumn{4}{|c|}{ Market adjusted return model } & \multicolumn{4}{|c|}{ Mean adjusted return model } \\
\hline & & -10 & & +10 & & -10 & & +10 & & -10 & & +10 \\
\hline & $\begin{array}{c}\text { CAR } \\
(\%)\end{array}$ & $\begin{array}{c}\text { T- } \\
\text { Statisti } \\
\text { cs }\end{array}$ & $\begin{array}{c}\text { CAR } \\
(\%)\end{array}$ & $\begin{array}{c}\text { T- } \\
\text { Statisti } \\
\text { cs }\end{array}$ & $\begin{array}{c}\text { CAR } \\
(\%)\end{array}$ & $\begin{array}{c}\text { T- } \\
\text { Statisti } \\
\text { cs }\end{array}$ & $\begin{array}{c}\text { CAR } \\
(\%)\end{array}$ & $\begin{array}{c}\text { T- } \\
\text { Statisti } \\
\text { cs }\end{array}$ & $\begin{array}{c}\text { CAR } \\
(\%)\end{array}$ & $\begin{array}{c}\text { T- } \\
\text { Statisti } \\
\text { cs }\end{array}$ & $\begin{array}{c}\text { CAR } \\
(\%)\end{array}$ & $\begin{array}{c}\text { T- } \\
\text { Statisti } \\
\text { cs }\end{array}$ \\
\hline HDFC & -6.44 & -1.63 & 13.58 & $\begin{array}{r}3.43 \\
* *\end{array}$ & -7.37 & $-1.86^{*}$ & -1.58 & -0.40 & -32.74 & $\begin{array}{r}- \\
8.26^{* *}\end{array}$ & 12.35 & $3.12^{* *}$ \\
\hline ICICI & -14.85 & $-3.72 * *$ & 21.39 & $5.36 * *$ & -18.08 & $-4.52 * *$ & -9.69 & $-2.43^{* *}$ & -43.11 & $\begin{array}{r}- \\
10.79 * \\
*\end{array}$ & 4.57 & 1.14 \\
\hline AXIS & -33.76 & $-8.32 * *$ & 63.17 & $\begin{array}{r}15.56 \\
* *\end{array}$ & -46.77 & $\begin{array}{r}- \\
11.52^{*} \\
*\end{array}$ & 10.90 & $2.68^{* *}$ & -70.11 & $\begin{array}{r}- \\
17.27 * \\
*\end{array}$ & 26.85 & $6.62^{* *}$ \\
\hline $\begin{array}{l}\text { Bandha } \\
\text { n }\end{array}$ & -36.48 & $-6.28 * *$ & 44.95 & $7.73 * *$ & -58.98 & $\begin{array}{r}- \\
10.15^{*} \\
*\end{array}$ & 8.15 & 1.40 & -78.83 & $\begin{array}{r}- \\
13.56^{*} \\
*\end{array}$ & 27.59 & $4.75^{* *}$ \\
\hline Federal & -32.69 & $-6.18^{* *}$ & 19.68 & $3.72 * *$ & -40.26 & $-7.61 * *$ & -7.99 & -1.51 & -64.29 & $\begin{array}{r}- \\
12.15^{*} \\
*\end{array}$ & 7.28 & 1.38 \\
\hline $\begin{array}{l}\text { IDFC } \\
\text { First }\end{array}$ & -6.49 & -1.21 & 30.54 & $5.70^{* *}$ & -29.48 & $-5.51^{* *}$ & -5.73 & -1.07 & -52.04 & $-9.72 * *$ & 11.01 & $2.06^{* *}$ \\
\hline $\begin{array}{l}\text { Indus } \\
\text { Ind }\end{array}$ & -33.55 & $-5.54 * *$ & 62.46 & $\begin{array}{r}10.31 \\
* *\end{array}$ & -80.82 & $\begin{array}{r}- \\
13.35^{*} \\
*\end{array}$ & 16.96 & $2.80^{* *}$ & -102.15 & $\begin{array}{r}- \\
16.87 * \\
*\end{array}$ & 34.93 & $5.77 * *$ \\
\hline Kotak & -8.41 & $2.8^{* *}$ & 9.88 & $4.79 * *$ & -6.05 & $-1.71 *$ & -17.03 & $-4.82^{* *}$ & -31.39 & $-8.88^{* *}$ & -3.08 & -0.87 \\
\hline RBL & -8.71 & -0.93 & -44.74 & $2.38^{-}{ }^{-}$ & -4.22 & -0.45 & -45.54 & $-4.87^{* *}$ & -25.95 & $-2.78^{* *}$ & -27.98 & $-2.99 * *$ \\
\hline $\begin{array}{l}\text { South } \\
\text { bank }\end{array}$ & -12.20 & $-2.33^{* *}$ & 36.18 & $6.92 * *$ & -15.19 & $-2.91 * *$ & 1.61 & 0.31 & -36.81 & $-7.04 * *$ & 19.29 & $3.69 * *$ \\
\hline SBI & -13.77 & $-2.52^{* *}$ & -1.99 & 0.36 & -13.52 & $-2.48^{* *}$ & -17.37 & $-3.18^{* *}$ & -38.10 & $-6.98 * *$ & -2.65 & -0.49 \\
\hline BoB & -12.02 & $-2.58^{* *}$ & -14.40 & $2.15^{-}$ & 2.89 & 0.52 & -29.43 & $-5.27 * *$ & -18.90 & $-3.38^{* *}$ & -11.93 & $-2.14 * *$ \\
\hline $\begin{array}{l}\text { Cental } \\
\text { Bank }\end{array}$ & -12.49 & $-3.04 * *$ & 19.71 & $4.80 * *$ & -30.49 & $-7.43^{* *}$ & -6.00 & -1.46 & -55.13 & $\begin{array}{r}- \\
13.44^{*} \\
*\end{array}$ & 8.66 & $2.11^{* *}$ \\
\hline BoI & -10.25 & $-1.86^{*}$ & 24.99 & $4.54 * *$ & 1.13 & 0.21 & -7.09 & -1.29 & -17.96 & $-3.26^{* *}$ & 13.11 & $2.38^{* *}$ \\
\hline $\begin{array}{l}\text { Canara } \\
\text { Bank }\end{array}$ & -17.13 & $-2.78^{* *}$ & 28.62 & $4.65 * *$ & -16.06 & $-2.61 * *$ & -8.53 & -1.39 & -35.89 & $-5.83^{* *}$ & 10.94 & $1.78^{*}$ \\
\hline $\begin{array}{l}\text { Indian } \\
\text { Bank }\end{array}$ & -18.91 & $4.48^{* *}$ & 24.51 & $3.46^{* *}$ & -16.12 & $-2.95^{* *}$ & -8.80 & -1.61 & -33.94 & $-6.20 * *$ & 12.67 & $2.32^{* *}$ \\
\hline IOB & -2.99 & -0.44 & 5.51 & 0.81 & 7.48 & 1.10 & -13.23 & $-1.94^{*}$ & -15.46 & $-2.27^{* *}$ & 3.12 & 0.46 \\
\hline PNB & -3.23 & -0.55 & -10.99 & $1.86^{*}$ & 16.27 & $2.75^{* *}$ & -22.93 & $-3.88^{* *}$ & -3.84 & -0.65 & -3.75 & -0.64 \\
\hline UCO & -9.49 & -1.01 & 3.77 & 0.40 & 1.60 & 0.17 & -7.71 & -0.82 & -22.33 & $-2.38^{* *}$ & 7.66 & 0.81 \\
\hline Union & -6.62 & -0.92 & 14.63 & $2.02 * *$ & 4.21 & 0.58 & -8.51 & -1.18 & -15.33 & $-2.12^{* *}$ & 11.25 & 1.56 \\
\hline
\end{tabular}


Table 8. AAR of $2^{\text {nd }}$ Event

\begin{tabular}{|c|c|c|c|c|c|c|c|c|c|}
\hline \multirow[b]{2}{*}{$\begin{array}{l}\text { Event } \\
\text { Days }\end{array}$} & \multirow{2}{*}{$\begin{array}{l}\text { Market } \\
\text { return mode } \\
\text { AAR }(\%)\end{array}$} & \multirow{2}{*}{$\begin{array}{l}\text { and risk } \\
\text { el } \\
\text { T-Statistics }\end{array}$} & \multirow{2}{*}{$\begin{array}{l}\text { adjusted } \\
\text { P-Value }\end{array}$} & \multicolumn{3}{|c|}{ Market adjusted return model } & \multicolumn{3}{|c|}{ Mean adjusted return model } \\
\hline & & & & $\operatorname{AAR}(\%)$ & T-Statistics & P-Value & $\operatorname{AAR}(\%)$ & T-Statistics & P-Value \\
\hline-10 & -2.42 & -1.26 & 0.22 & -0.88 & -0.44 & 0.67 & -3.10 & -1.60 & 0.12 \\
\hline-9 & -4.34 & $-2.26 * *$ & 0.04 & -1.00 & -0.49 & 0.63 & -5.73 & $-2.96 * *$ & 0.01 \\
\hline-8 & -0.60 & -0.31 & 0.76 & -0.92 & -0.46 & 0.65 & -0.57 & -0.29 & 0.77 \\
\hline-7 & 5.32 & $2.77 * *$ & 0.01 & 11.29 & $5.60 * *$ & 0.00 & 2.91 & $1.68^{*}$ & 0.09 \\
\hline-6 & -6.45 & $-3.36 * *$ & 0.00 & -9.42 & $-4.67 * *$ & 0.00 & -5.39 & $-2.79 * *$ & 0.01 \\
\hline-5 & -0.16 & -0.08 & 0.94 & 5.27 & $2.62^{* *}$ & 0.02 & -2.35 & -1.22 & 0.24 \\
\hline-4 & -4.16 & $-2.17 * *$ & 0.04 & -2.61 & -1.29 & 0.21 & -4.86 & $-2.51 * *$ & 0.02 \\
\hline-3 & 0.64 & 0.33 & 0.74 & 6.08 & $3.02^{* *}$ & 0.01 & 0.65 & 0.34 & 0.74 \\
\hline-2 & -1.10 & -0.57 & 0.57 & 0.40 & 0.20 & 0.85 & -1.77 & -0.91 & 0.37 \\
\hline-1 & -5.43 & $-2.83^{* *}$ & 0.01 & -9.80 & $-4.86^{* *}$ & 0.00 & -3.84 & $-1.98^{* *}$ & 0.04 \\
\hline 0 & 2.63 & 1.37 & 0.19 & 12.37 & $6.14^{* *}$ & 0.00 & -1.24 & -0.64 & 0.53 \\
\hline 1 & 6.51 & $3.39 * *$ & 0.00 & 4.45 & $2.21^{* *}$ & 0.04 & 7.22 & $3.73^{* *}$ & 0.00 \\
\hline 2 & 2.55 & 1.33 & 0.20 & -2.35 & -1.17 & 0.26 & 4.36 & $2.25^{* *}$ & 0.04 \\
\hline 3 & -1.41 & -0.74 & 0.47 & -4.44 & $-2.20 * *$ & 0.04 & -0.33 & -0.17 & 0.86 \\
\hline 4 & -5.07 & $-2.64 * *$ & 0.02 & -5.50 & $-2.73^{* *}$ & 0.01 & -5.00 & $-2.58^{* *}$ & 0.02 \\
\hline 5 & 3.94 & $2.05^{* *}$ & 0.05 & 6.89 & $3.42^{* *}$ & 0.00 & 2.71 & 1.40 & 0.18 \\
\hline 6 & -2.58 & -1.34 & 0.19 & -5.56 & $-2.76^{* *}$ & 0.01 & -1.51 & -0.78 & 0.44 \\
\hline 7 & -0.61 & -0.32 & 0.75 & 2.05 & 1.02 & 0.32 & -1.74 & -0.90 & 0.38 \\
\hline 8 & 2.68 & 1.39 & 0.18 & 3.90 & 1.94* & 0.07 & 2.11 & 1.09 & 0.29 \\
\hline 9 & -2.30 & -1.20 & 0.25 & -8.63 & $-4.28^{* *}$ & 0.00 & 0.06 & 0.03 & 0.98 \\
\hline 10 & 4.05 & $2.11^{* *}$ & 0.048 & 4.13 & $2.05^{* *}$ & 0.04 & 3.93 & $2.03 * *$ & 0.04 \\
\hline
\end{tabular}

* indicates significant at $10 \%$ level of significance.

** indicates significant at $5 \%$ level of significance

Source: Author's own estimation

Table 9 T-statistics and $P$ value of CAAR of $2^{\text {nd }}$ Event

\begin{tabular}{|c|c|c|c|c|c|c|}
\hline Model & $\begin{array}{l}\text { Market and } \\
\text { adjusted return mode }\end{array}$ & risk & $\begin{array}{l}\text { Market } \\
\text { return model }\end{array}$ & adjusted & $\begin{array}{l}\text { Mean } \\
\text { return model }\end{array}$ & adjusted \\
\hline Event days & T-Statistics & P-Value & T-Statistics & P-Value & T-Statistics & P-Value \\
\hline-10 & $-3.08 * *$ & 0.01 & $-1.69 *$ & 0.09 & $-3.93 * *$ & 0.00 \\
\hline 10 & $1.71 *$ & 0.09 & 1.15 & 0.26 & $1.93^{*}$ & 0.07 \\
\hline
\end{tabular}

$*$ indicates significant at $10 \%$ level of significance.

** indicates significant at $5 \%$ level of significance.

Source: Author's own estimation 


\section{DISCUSSION}

COVID-19 has impacted both the economy and also the psyche of the investors. Therefore, in pandemic, not only does one need to formulate strategies to prevent future public health issues but also plan for financial safety and security. Stock prices carry the potential for future earnings, and investors apprehend that the epidemic may stunt the economic growth affecting their earnings. In a country like India, banking sector has a major role to play in the growth of the economy. Therefore, this study aimed to examine the immediate impact of COVID-19 on stock prices of major banks in India. The study complements the literature by investigating the unforeseen consequences of a dreaded disease on the Indian banking sector. From the perspective of an investor, the outcomes of this study demonstrate the significance of investment risks posed by a sudden occurrence of an event.

Examination of the performance of nifty banks on two important events such as the detection of the first case of COVID-19 and the implementation of the first phase of lockdown, reveals that the first event had insignificant impact on the price of the bank shares as compared to the second event, which had a significant impact on of the bank share price. The impact of the event on the AR and CAR of banks are negative in pre-event period while it is positive in the post-event period. It shows how the fear of unknown and uncertainty, that came in the form of virus, could grip the investors' confidence. However, true to the human resilience and adaptability, investors were not very wary of the lockdowns and they stayed positive. As a result of which both the AR and CAR for post-event period is found to be positive, which can also be evident from the positive AAR and CAAR of the second event for both the public and private banks. Post-lockdown, the market has seen a favorable trend, indicating the news of the lockdown had a beneficial impact on the nifty banks. This suggests that investors could have benefitted from the irregularity in trend and certain positive peaks seen throughout this period.

\section{CONCLUSION}

Coronavirus did not only affect the health sector but also brought damages to labor market, goods, services, and the entire industry. This has also impacted the perspectives of people, those of investors, in particular. Though there are vaccines developed by several pharmaceutical companies, the efficacy of these vaccines is always controversial. Moreover, 
there have been problems like vaccine diplomacies, short supplies, legal rumbles, and so on. As a result, the outbreak has indeed been a global crisis affecting the entire world economy. Though there is a sign of rebound, in some cases, the stock markets across the globe have been damaged to a large scale. The present stock markets in India are facing sharp volatility due to unanticipated shocks. Banks being the catalyst of growth, "the COVID-19 pandemic poses a significant threat to the sustainability of banks globally and it would be worse in developing and emerging economies, where financial systems are weak" (Barua and Barua, 2020). Therefore, this paper examined the performance of nifty banks during the pandemic by taking two important events in India namely detection of the first case of COVID-19 and implementation of the lockdown. In order to test the impacts of these events, this paper used three different models of event study (i.e., market and risk adjusted return, market adjusted return, and mean adjusted return model) in order to check the robustness of the study. The study found that the first event had an insignificant impact on the share prices of nifty banks, whereas the second event had a significant impact on the nifty banks' share prices. The AR and CAR of banks in the pre-event period are negative while it is positive for the post-event period. It implies that the markets reacted positively to the news of lockdown, which is similar to the study conducted by Alam et al. (2020). The overall impact of the events was mixed as the AAR and CAAR of the first event are insignificant while the AAR and CAAR of the second event are statistically significant. The CAAR of the pre-lockdown period is significant but negative while it is positive and statistically significant during the post-lockdown period resulting in rejection of the null hypothesis for the second event.

\section{REFERENCES}

Alam, M. N., M. S. Alam, and K. Chavali. 2020. Stock market response during COVID-19 lockdown period in India: an event study. Journal of Asian Finance, Economics and Business 7 (7): 131-137

Ashraf, B. 2020. Stock markets' reaction to COVID-19: cases or fatalities? Research in International Business and Finance 54: 1-7

Arjani, N. and G. Paulin. 2013. Lessons from the Financial Crisis: Bank Performance and Regulatory Reform. Bank of Canada Discussion Paper: 1-36. 
Barua, B. and S. Barua. 2020. COVID-19 implications for banks: the case of an emerging economy. SSRN Electronic Journal.

Barua, S. 2020. Understanding coronanomics: the economic implications of the coronavirus (COVID-19) pandemic. SSRN Electronic Journal.

Berger, A. and C. Bouwman. 2013. How does capital affect bank performance during financial crises? Journal Of Financial Economics, 109(1): 146-176.

Brown, S. and J. Warner. 1985. Using daily stock returns. Journal of Financial Economics 14 (1): 3-31.

Fernandes, N. 2020. Economic Effects of Coronavirus Outbreak (COVID-19) on the World Economy. SSRN Electronic Journal.

Heyden, K. and T. Heyden. 2020. Market reactions to the arrival and containment of COVID-19: an event study. SSRN Electronic Journal.

Jamir, I. 2020. Forecasting potential impact of COVID-19 outbreak on India's GDP using ARIMA model. SSRN Electronic Journal.

Kumar, V. and B. Bhatia. 2018. The effect of demonetization in Indian stock market with special reference to sectorial indices: an event study. SSRN Electronic Journal.

Liu, H., A. Manzoor, C. Wang, L. Zhang, and Z. Manzoor. 2020. The COVID-19 outbreak and affected countries stock markets response. International Journal of Environmental Research and Public Health 17 (8): 1-19

Mahajan, S. 2020. Impact of COVID-19 on financial health in India: managing financial health in challenging times. SSRN Electronic Journal

McWilliams, A. and D. Siegel. 1997. Event studies in management research: theoretical and empirical issues. Academy of Management Journal 40 (3): 626-657

Naidenova, I., P. Parshakov, and E. Shakina. 2020. Idiosyncratic and systematic shocks of COVID-19 pandemic on financial markets. SSRN Electronic Journal

Ozili, P. 2020. COVID-19 in Africa: socio-economic impact, policy response and opportunities. International Journal of Sociology and Social Policy,

Peni, E. and S. Vähämaa. 2011. Did Good Corporate Governance Improve Bank Performance during the Financial Crisis? Journal of Financial Services Research, 41(1-2): 19-35.

Rakshit, D. and A. Paul. 2020. Impact of COVID-19 on sectors of Indian economy and business survival strategies. International Journal of Engineering and Management Research 10 (03): 51-55. 
Ramelli, S. and A. Wagner. 2020. Feverish stock price reactions to COVID-19. The Review of Corporate Finance Studies.

Singh, B. 2020. Impact of COVID-19 on rural economy in India. SSRN Electronic Journal.

Sułkowski, Ł. 2020. COVID-19 pandemic: recession, virtual revolution leading to deglobalization? Journal of Intercultural Management 12 (1): 1-11.

\section{APPENDIX}

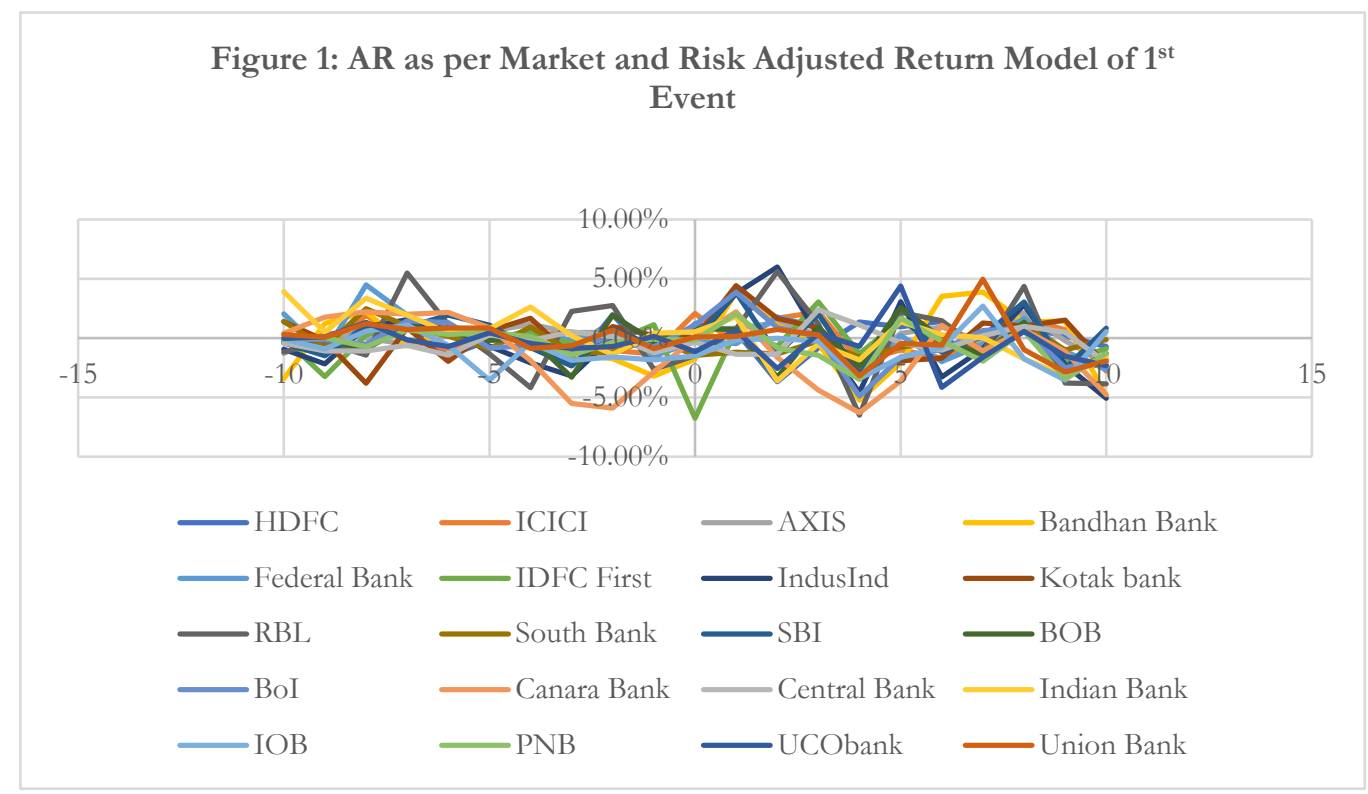

Source: Author's own estimation 
Figure 2: AR as per Market Adjusted Model of 1st Event

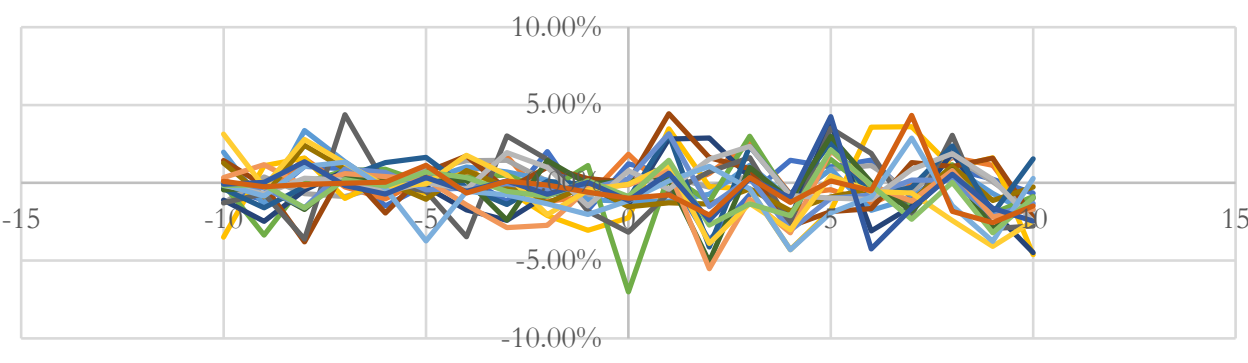

$\begin{array}{llll}\text { HDFC } & \text { ICICI } & \text { AXIS } & \text { Aandhan Bank } \\ \text { Federal Bank } & \text { IDFC First } & \text { - IndusInd } & \text { Kotak bank } \\ \text { RBL } & \text { South Bank } & \text { SBI } \\ \text { BoI } & \text { Canara Bank } & \text { Central Bank } & \text { Bndian Bank } \\ \text { IOB } & \text { PNB } & \text { UCObank } & \text { Union Bank }\end{array}$

Source: Author's own estimation

Figure 3: AR as per Mean Adjusted Return Model of 1st Event
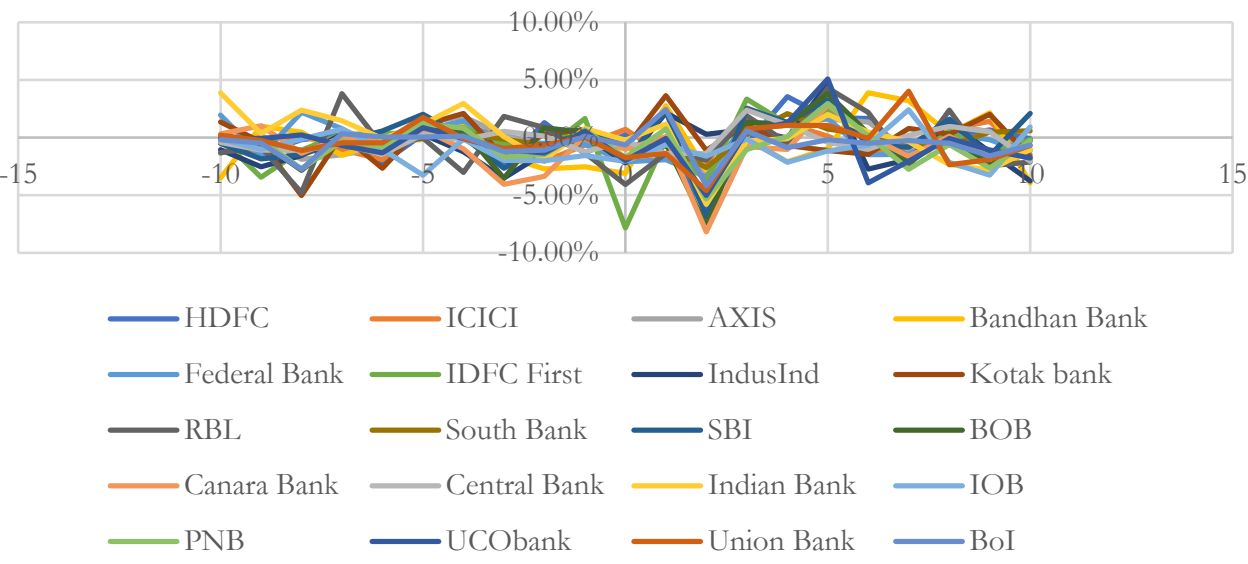

Source: Author's own estimation 
Figure 4: AR of $2^{\text {nd }}$ Event as Per Market and Risk Adjusted Return Model

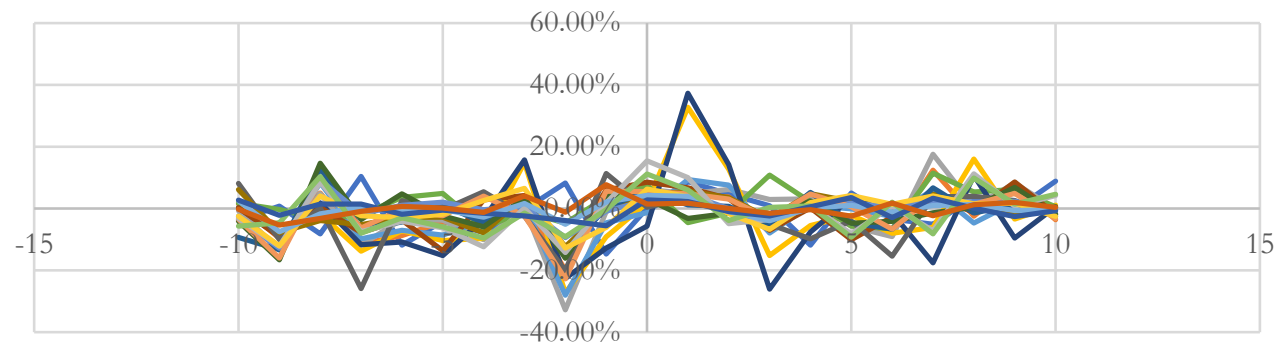
$\longrightarrow \mathrm{HDFC}$
- ICICI
AXIS
-Bandhan Bank
- Federal Bank

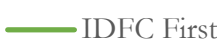
- IndusInd
- Kotak bank
$-\mathrm{RBL}$
- South Bank
- SBI
$\mathrm{BOB}$
$\longrightarrow$ BoI
Canara Bank
Central Bank
Indian Bank
IOB
PNB
—UCObank
-Union Bank

Source: Author's own estimation

Figure 5: AR of 2nd Event as Per Market Adjusted Return Model

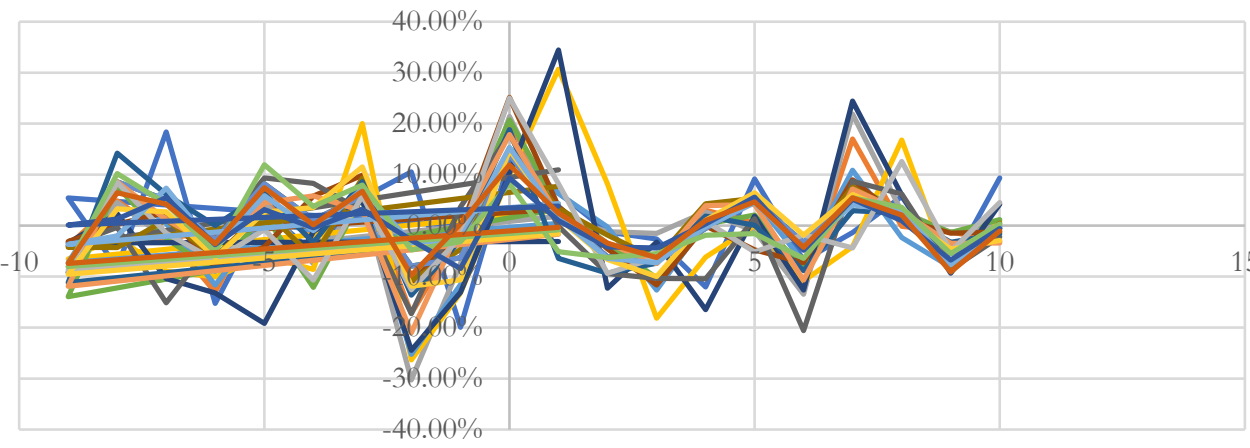
$\longrightarrow \mathrm{HDFC}$
- ICICI
AXIS
Bandhan Bank
- Federal Bank
- IDFC First
- IndusInd
Kotak bank
$\longrightarrow$ RBL
- South Bank
$\longrightarrow \mathrm{SBI}$
$\mathrm{BOB}$
$-\mathrm{BoI}$
Canara Bank
Central Bank
- IOB
$\longrightarrow$ PNB
UCObank
Indian Bank
—Union Bank 
Source: Author's own estimation

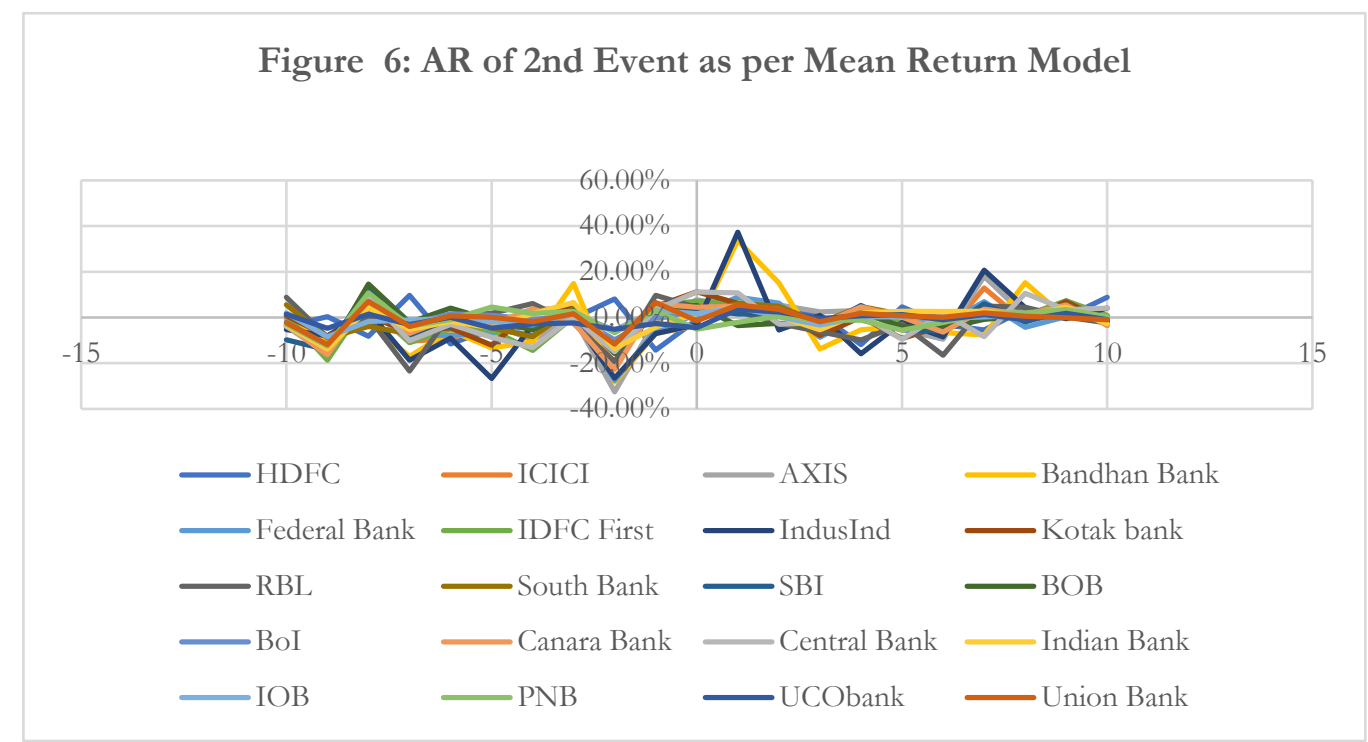

Source: Author's own estimation 